\title{
Octopus vulgaris in the Caribbean is a specializing generalist
}

\author{
Roland C. Anderson ${ }^{1, *}$, James B. Wood ${ }^{2}$, Jennifer A. Mather ${ }^{3}$ \\ ${ }^{1}$ The Seattle Aquarium, 1483 Alaskan Way, Seattle, Washington 98101, USA \\ ${ }^{2}$ Bermuda Institute of Ocean Sciences, 17 Biological Lane, Ferry Reach, St. George's GE 01, Bermuda \\ ${ }^{3}$ Psychology Department, University of Lethbridge, 4401 University Drive, Lethbridge, Alberta T1K 3M4, Canada
}

\begin{abstract}
The diet of Octopus vulgaris was determined from the remains of 649 prey items gathered from the middens of 38 dens in a small area off the Caribbean island of Bonaire. Remains of 35 species of gastropod (19\% of the total), 19 bivalves (51\%) and 21 crustaceans (30\%) were identified and examined for mode of entry into hard-shelled prey. Although $60 \%$ of the gastropods were drilled, neither the size/weight ratio nor the presence of an operculum determined whether drilling occurred. There were strong differences in prey preference among individual octopuses, and the Cardona niche breadth index $\left(\mathrm{B}^{\prime}\right)$ of the midden items was 0.08 , indicative of specialization. Examples include the exclusive preference for Pinna carnea by one den occupant. This study, by focusing on assessment of preference at specific den locations, is the first to show that while the population had a wide choice of prey items, the individual choices were much narrower, indicating that octopuses were specializing generalists.
\end{abstract}

KEY WORDS: Octopus vulgaris · Octopus $\cdot$ Diet $\cdot$ Middens $\cdot$ Specializing generalist

\section{INTRODUCTION}

The diet of octopuses has been determined largely by examining middens, the remains of food items outside their dens (Altman 1967, Hartwick et al. 1978, Ambrose 1983, Ambrose \& Nelson 1983, Mather 1991a, Gonçalves et al. 1994, Cortez et al. 1995, Anderson 1997, Dodge \& Scheel 1999, Anderson et al. 1999, Scheel et al. 2007). Aristotle was the first to record this phenomenon, noting that fishermen find octopuses by the shells left outside their dens (Balme 1991).

There can be several challenges to using this method for determining octopus prey. Prey remains can be moved by currents or waves (Mather 1991a) or by biotic factors such as hermit crabs looking for a new shell (Ambrose 1983). Fish also commonly follow octopuses to feed on scraps left by the octopus and thus move prey remains (Hartwick \& Thorarinsson 1978, Mather 1992). Therefore, researchers using this method to determine octopus diets must retrieve the prey remains quickly after they are discarded. Furthermore, Ambrose (1983) cautions that examination of middens for octopus prey does not provide information on rates of consumption because of shell dispersal. He also hypothesized that octopuses push or carry shells away from the den to reduce their visibility to possible predators. These difficulties often lead researchers to sum data and ignore individual octopuses.

Octopus vulgaris is a widespread species originally reported from the Mediterranean. Its prey has been reported as diverse (Nigmatullin \& Ostapenko 1976), suggesting that this species is a generalist, but there are hints that individual octopuses may also specialize (Ambrose 1983, Anderson et al. 1999, Dodge \& Scheel 1999, Scheel et al. 2007, J. A. Mather unpubl. obs.). Since the Caribbean Sea has a diverse array of potential mollusks and crustaceans (Miloslavich \& Klein 2005) available as prey, we examined the prey items of $O$. vulgaris there to look for such specialization.

A generalist octopus needs to use a variety of penetration techniques into hard-shelled prey (Anderson \& Mather 2007). For bivalves, prey handling appears simple: strength of adductor muscles and thickness of shells should be a predictor of opening techniques 
(Anderson \& Mather 2007). Octopus handling of gastropod prey is more complicated. Wodinsky (1973) and Nixon \& Maconnachie (1988) studied the techniques for opening gastropods but there is no listing of prey characteristics that predicts opening methods. Possible entries on such a list would be gastropod possession of an operculum, foot strength, thickness of shell, shape, size, and possession of spines on the shell. The evolution of such features is discussed by Vermeij (1993), who coined the phrase 'the great arms race' as a description of the co-evolution of predators and prey.

The opportunity to sample a large number of octopus dens in a limited area over a period of years allowed us to answer questions about prey choice and penetration techniques in the field and illuminate some of the effects in these aspects of predatory octopuses.

\section{METHODS}

Midden remains from dens occupied by the common octopus Octopus vulgaris were collected while the authors were snorkeling on the lee side of the island of Bonaire in the southern Caribbean, between the island's power plant and the Eden Beach Resort. Middens were sampled along $1 \mathrm{~km}$ of shoreline at a water depth of 0.5 to $5 \mathrm{~m}$ once or twice a day for 1 mo during the months of May and June in 3 years (2001-2003). All dens sampled had been occupied by an octopus at least once during $48 \mathrm{~h}$. Although some older, unoccupied dens were seen, their contents were not sampled and their midden items soon dispersed and disappeared (Ambrose 1983). Mather (1991a) found that $50 \%$ of midden contents were lost in $5 \mathrm{~d}$. This species of octopus does not form defended territories and individuals have overlapping ranges (Mather 1991a,b), thus ensuring equal access to prey.

This sampling design was low impact, and we did nothing that would affect the living octopuses or their living prey. Hence, we did not capture or tag live animals or take live samples of octopuses and their prey.

Samples were taken from a mean of 6 dens (range 4 to 12 ) every 1 or $2 \mathrm{~d}$. Although 3 other octopus species (Octopus filosus, $O$. briareus, and $O$. defilippi) were observed along this coastline during the course of this study and others might be expected (Adam 1937), $O$. vulgaris was the only species observed in dens with middens. Midden materials were identified to species. Mollusk species were identified using Abbott (1974), Warmke \& Abbott (1961), and DeYong \& Coomans (1988). Crabs were identified using Rathbun (1918, $1925,1930)$. Shells taken from the dens were examined for damage and drill holes using the methods of Nixon \& Maconnachie (1988), Mather \& Nixon (1995) and Anderson \& Mather (2007).
We evaluated all gastropod shells to determine whether those with heavier shells and/or opercula were drilled more frequently than those with thin shells (see Table 1). Since the data were not normally distributed, we ran a Kruskal-Wallis non-parametric test (Zar 1996) to determine whether the presence of an operculum (independent variable) affected the chance of being drilled by an octopus (dependent variable). Length, width, height and mass were taken and a size to weight ratio calculated $([\mathrm{L} \times \mathrm{W} \times \mathrm{H}] / \mathrm{wt})$; this ratio was used as the independent variable in a regression whose dependent variable was frequency of drilling.

Cardona's (1991) trophic niche breadth index (B') was determined for the total number of species eaten. Because prey remains were often collected from many dens and the selection summed across individuals, it was usually difficult to assess the choices of each octopus rather than the population. With a systematic collecting effort at individual dens, these can be separated. The B' index, allows assessment of specialization of individuals, with values ranging from 0.01 (highly specialist) to 1.00 (complete generalist).

\section{RESULTS}

The remains of 649 prey of 75 species were found in 38 octopus den middens (Table 2). They consisted of 35 species of gastropods $(19 \%$ of the total remains), 21 crustaceans (30\%) and 19 bivalve species $(51 \%)$. For example on 4 June 2003, the midden in front of octopus 'Lynn' contained remains of 2 Chlamys ornatus, 2 Mithrax hemphilli, 3 M. caribbaeum, 1 Alphaeus sp., 1 Cymatium pileare and 3 Ctenoides pellucida, while on the same day $50 \mathrm{~m}$ away, the midden of octopus 'Daniel' only contained the remains of 3 Pinna carnea.

Many of the gastropods $(60 \%)$ were drilled. A Kruskal-Wallis test to determine whether having an operculum dictated the choice of prey entry was not significant $(p=0.127)$ and a regression testing whether

Table 1. Octopus vulgaris. Likelihood of drilling (\% of shells) on common molluskan prey species

\begin{tabular}{|lrcc|}
\hline Type of shell & N & \% drilled & Has operculum? \\
\hline Gastropod & & & \\
Cymatium pileare & 11 & 33 & Yes \\
Cypraea spp. & 8 & 60 & No \\
Nitadella laevigata & 11 & 73 & Yes \\
Polinices lacteus & 7 & 78 & Yes \\
Strombus gigas & 12 & 100 & Yes \\
Bivalve & & & \\
Antigona listeri & 2 & 100 & \\
Arca zebra & 10 & 100 & \\
Barbatia tenera & 43 & 0 & \\
Chlamys ornatus & 136 & 0 & \\
\hline
\end{tabular}


Table 2. Octopus vulgaris. The remains of individuals $(n=649)$ of 75 prey species found outside dens of 38 octopuses off Bonaire. The number of prey individuals found is listed after each species

\begin{tabular}{|c|c|c|}
\hline Bivalves & Crustaceans & Gastropods \\
\hline $\begin{array}{l}\text { Antigona listeri } 2 \\
\text { Arca zebra } 10 \\
\text { Antigona listeri } 2 \\
\text { Barbatia candida } 20 \\
\text { Pinna carnea } 17 \\
\text { Barbatia domingensis } 1 \\
\text { Barbatia tenera } 43 \\
\text { Chlamys ornatus } 136 \\
\text { Chlamys sentis } 31 \\
\text { Codakia orbicularis } 9 \\
\text { Codakia pectinella } 1 \\
\text { Ctenoides (=Lima) scabra } 31 \\
\text { Ctenoides (=Lima) pellucida } 1 \\
\text { Ctenoides (=Lima) lima } 5 \\
\text { Divaricella quadrisulcata } 5 \\
\text { Papyridea semisulcata } 1 \\
\text { Papyridea soleniformes } 4 \\
\text { Pectin ziczac } 1 \\
\text { Spondylus americanus } 3 \\
\text { Tellina radiata } 1 \\
\text { Trachycardium muricatum } 5\end{array}$ & $\begin{array}{l}\text { Actaea rufopunctada } 6 \\
\text { Alphaeus sp } 1 \\
\text { Calappa gallus } 9 \\
\text { Cronius ruber } 4 \\
\text { Dardanus venosus } 1 \\
\text { Ebalia cariosa } 1 \\
\text { Mithrax caribbaeus } 60 \\
\text { Mithrax coryphe } 2 \\
\text { Mithrax hemphilli } 55 \\
\text { Mithrax hispidus } 13 \\
\text { Mithrax ruber } 1 \\
\text { Mithrax tuberculosus } 3 \\
\text { Mithrax verrucosus } 4 \\
\text { Percnon gibbesi } 5 \\
\text { Pitho anisodon } 2 \\
\text { Portunus sebae } 3 \\
\text { Stenorhynchus seticornis } 1 \\
\text { Xanthodius denticulatus } 6\end{array}$ & $\begin{array}{l}\text { Astraea caelata } 5 \\
\text { Bursa cubaniana } 6 \\
\text { Cantharus auritulus } 4 \\
\text { Cantharus tinctus } 1 \\
\text { Ceritheum litteratum } 1 \\
\text { Ceritheum nodulosa } 1 \\
\text { Charonia variegata } 1 \\
\text { Conella ovulata } 2 \\
\text { Cymatium caribbaeum } 1 \\
\text { Cymatium pileare } 11 \\
\text { Cymatium poulseni } 1 \\
\text { Cypraea acicularis } 4 \\
\text { Cypraea cinerea } 4 \\
\text { Diodora variegata1 } \\
\text { Emarginula pumila } 1 \\
\text { Fissurella barbadensis } 2 \\
\text { Fissurella nimbosa } 1 \\
\text { Hemitoma octoradiata } 1 \\
\text { Leucozonia nassa } 1 \\
\text { Livona pica } 4 \\
\text { Mitra nodulosa } 3 \\
\text { Nerita fulgarans } 1 \\
\text { Nerita tessellata } 1 \\
\text { Nerita versicolor } 3 \\
\text { Nitadella laevigata } 11 \\
\text { Oliva reticularis } 1 \\
\text { Pisania pusio } 4 \\
\text { Polinices lacteus } 7 \\
\text { Pyramidella dolabrata } 1 \\
\text { Strombus gigas } 12 \\
\text { Thais deltoidea } 5 \\
\text { Trivia pediculus } 4 \\
\text { Vasum capitellum } 4 \\
\text { Voluta musica } 2 \\
\text { Xenophora conchyliophora } 1\end{array}$ \\
\hline
\end{tabular}

multiple phyla (Hartwick et al. 1978, Ambrose 1983, Anderson et al. 1999, Dodge \& Scheel 1999), but not nearly as many as reported here. This may reflect lower sampling intensity in other studies (but see Dodge \& Scheel 1999) or that the Caribbean Sea, which is known for the diversity of its fauna (Miloslavich \& Klein 2005), may provide a wider selection of potential prey.

Octopuses are assumed to be generalist feeders; Hanlon \& Messenger (1996) called them 'opportunistic feeders', so it was surprising to find that some individuals were specializing on certain taxa or even single species. The remains of only Pinna carnea at one den was an extreme example. Dens were often much less than $100 \mathrm{~m}$ apart within similar areas of coral rock, rubble and sand. Such a distance is typically covered by a foraging octopus (Mather 1991b) so the resources were equally available to the octopuses in the study area. Individuals of at least 1 other octopus, Enteroctopus dofleini, which has a preference for crabs (Hartwick et al. 1978, Ambrose 1983, Anderson 1996, Dodge \& Scheel 1999), can also specialize on other prey.

size to weight ratio was significant was also non-significant. Individual Antigona listeri and Arca zebra prey were always drilled over one of the adductor muscles. The bivalves that were most commonly found in the middens (Chlamys ornatus, C. sentis, Barbatia tenera and $B$. candida) were never drilled, and shells of the fragile Pinna carnea were always broken. In front of one octopus den ('Daniel'), all remains were of $P$. carnea. Crab carapaces were rarely drilled; only 1 of 194 crab carapaces of 16 species was drilled and 2 of 3 Calappa chelae were drilled, both on the ventral side. A B' index value (Cardona 1991) of 0.08 was observed, well within the specialist end of the ecological range.

\section{DISCUSSION}

It was surprising to find the remains of so many prey species (75) in the middens of Octopus vulgaris in the Caribbean, more than were found in the Mediterranean (Ambrose \& Nelson 1983) or Bermuda (Mather 1991a). Other octopus species consume many different taxa of
Where individual B' values have been calculated for octopuses, they are often narrow. The $\mathrm{B}^{\prime}$ value for Octopus rubescens found in beer bottles on a sand/ mud habitat in the northeastern Pacific was 0.24 (Anderson et al. 1999). A B' value of 0.28 was found for O. cyanea in Hawaii (J. A. Mather unpubl. data), which consumed crabs almost exclusively (Yarnall 1969). The low $B^{\prime}$ value found here $\left(B^{\prime}=0.08\right)$ indicates that individual $O$. vulgaris are specialists (Cardona 1991); however, the population ate 75 different species, indicating otherwise. The fact that octopuses can be specializing generalists may allow them to take advantage of easily available and localized prey abundance.

Why might individual octopuses be specialists? It is often taken for granted that generalists sample abundant prey (see Ambrose 1983 for Octopus bimaculoides, which prefers uncommon species in the laboratory, but takes common species in the field), and it is assumed that specialization increases efficiency. Alternatively, Krebs \& Davies (1997) assumed that predators take prey on the basis of the balance between energy 
output to find and consume, and input from caloric intake. Such a balance was obvious in prey selection by Enteroctopus dofleini in the field (Scheel et al. 2007) and in the laboratory (Anderson \& Mather 2007), where octopuses switched preferences when the ease of obtaining food was altered. A third possibility, based on the intelligence of octopuses (Mather 1995), is that each individual may sample local prey and learn which of them are easily available or easily located by the individual's foraging strategies. Such learning might assure that the species is a generalist, but the individuals within any population are at least temporary specialists. Octopuses have different personalities (Mather \& Anderson 1993, Sinn et al. 2001), which may benefit the species when paralarvae settle onto different substrata and thence pursue different prey, leading to specialization.

Acknowledgements. We thank L. Mather for logistical support, and S. Zimsen and W. Deckel for statistical assistance. G. Jensen of the University of Washington, M. Wicksten of the Texas A\&M University and P. Mikkelsen of the Paleontological Research Institution assisted with identification of midden items.

\section{LITERATURE CITED}

Abbott RT (1974) American seashells, 2nd edn. Van Nostrand, New York

Adam W (1937) Cephalopodes des Iles Bonaire et Curaçao (avec une recsion du genre Sepioteuthis de la côte americaine). Capita Zool 8:1-29

Altman JS (1967) The behaviour of Octopus vulgaris Lam. in its natural habitat: a pilot study. Underwater Assoc Rep 1966-67:77-83

Ambrose RF (1983) Midden formation by octopuses: the role of biotic and abiotic factors. Mar Behav Physiol 10: 137-144

Ambrose RF, Nelson BV (1983) Predation by Octopus vulgaris in the Mediterranean. Ecology 4:251-261

Anderson RC (1996) What does a giant Pacific octopus eat? Of Sea \& Shore 18:221-222

Anderson RC, Mather JA (2007) The packaging problem: bivalve prey selection and prey entry techniques of the octopus Enteroctopus dofleini. J Comp Psychol 121: 300-305

Anderson RC, Hughes PD, Mather JA, Steele CW (1999) Determination of the diet of Octopus rubescens Berry, 1953 (Cephalopoda: Octopodidae) through examination of its beer bottle dens in Puget Sound. Malacologia 41: $455-460$

Anderson TJ (1997) Habitat selection and shelter use by Octopus tetricus. Mar Ecol Prog Ser 150:137-148

Balme DM (Translator) (1991) Aristotle: history of animals. Harvard University Press, Cambridge, MA

Cardona L (1991) Measurement of trophic niche breadth using occurrence frequencies. J Fish Biol 39:901-903

Cortez T, Castro BG, Guerra A (1995) Feeding dynamics of Octopus mimus (Mollusca: Cephalopoda) in northern Chile waters. Mar Biol 123:497-503

De Yong KM, Coomans HE (1988) Marine gastropods from Curaçao, Aruba and Bonaire. EJ Brill, Leiden

Dodge R, Scheel D (1999) Remains of the prey — recognizing

Editorial responsibility: Charles Birkeland,

Honolulu, Hawaii, USA the midden piles of Octopus dofleini (Wülker). Veliger 42:260-266

Gonçalves JM, Estacio SV, Martins HR (1994) Octopus prey remains found in middens in Faial Island (Azores), with notes on the behaviour in natural habitat. In: Messenger JB (ed) Poster-Napoli CIAC (Cephalopod International Advisory Council) Symposium 1994. Cephalopod International Advisory Council, Naples

Hanlon RT, Messenger JB (1996) Cephalopod behaviour. Cambridge University Press, Cambridge

Hartwick EB, Thorarinsson G (1978) Den associates of the giant Pacific octopus Octopus dofleini (Wülker). Ophelia 17:163-166

Hartwick EB, Thorarinsson G, Tulloch L (1978) Methods of attack by Octopus dofleini (Wülker) on captured bivalve and gastropod prey. Mar Behav Physiol 5:193-200

Kreb JR, Davies NB (1997) Behavioural ecology: an evolutionary approach, 4th edn. Blackwell Science, Oxford

Mather JA (1991a) Foraging, feeding and prey remains in middens of juvenile Octopus vulgaris (Mollusca: Cephalopoda). J Zool (Lond) 224:27-39

Mather JA (1991b) Navigation by spatial memory and use of visual landmarks in octopuses. J Comp Physiol 168: 491-497

Mather JA (1992) Interactions of juvenile Octopus vulgaris with scavaging and territorial fishes. Mar Behav Physiol 19:175-182

Mather JA (1995) Cognition in cephalopods. Adv Study Behav 24:316-353

Mather JA, Anderson RC (1993) Personalities of octopuses (Octopus rubescens). J Comp Psychol 107:336-340

Mather JA, Nixon M (1995) Octopus vulgaris (Cephalopoda) drills the chelae of crabs in Bermuda. J Molluscan Stud 61:405-406

Miloslavich P, Klein E (2005) Caribbean marine biodiversity. DE Stech, Lancaster, PA

Nigmatullin CM, Ostapenko AA (1976) Feeding of Octopus vulgaris Lam. from the northwest African coast. ICES Shellfish and Benthos Committee, Document, CM 1976/K 6:1-15

Nixon M, Maconnachie E (1988) Drilling by Octopus vulgaris (Mollusca: Cephalopoda) in the Mediterranean. J Zool (Lond) 216:687-716

Rathbun MJ (1918) Grapsoid crabs of America. Government Printing Office, Washington, DC

Rathbun MJ (1925) Spider crabs of America. Government Printing Office, Washington, DC

Rathbun MJ (1930) Cancroid crabs of America. Government Printing Office, Washington, DC

Scheel D, Lauster A, Vincent TLS, Theile R (2007) Habitat ecology of Enteroctopus dofleini from middens and live prey surveys in Prince William Sound, Alaska. In: Landman NH, Davis RA, Mapes RH (eds) Cephalopods present and past: new insights and fresh perspectives. Springer, Dordrecht, p 434-458

> Sinn DL, Perrin NA, Mather JA, Anderson RC (2001) Early temperamental traits in an octopus (Octopus bimaculoides). J Comp Psychol 115:351-364

Vermeij G (1993) The natural history of shells. Princeton University Press, Princeton, NJ

Warmke GL, Abbott RT (1961) Caribbean seashells. Dover Publications, New York

Wodinsky J (1973) Mechanism of hole boring in Octopus vulgaris. J Gen Psychol 88:179-183

> Yarnall JL (1969) Aspects of the behaviour of Octopus cyanea. Anim Behav 17:747-775

Zar JH (1996) Biostatistical analysis, 3rd edn. Prentice Hall, Englewood Cliffs, NJ

Submitted: March 6, 2008; Accepted: July 16, 2008

Proofs received from author(s): October 14, 2008 